\title{
Long-Term Efficacy and Safety Profile of Lanthanum Carbonate: Results for up to 6 Years of Treatment
}

\author{
Alastair J. Hutchison ${ }^{a}$ M. Edwina Barnett ${ }^{b}$ Rolfdieter Krause ${ }^{c}$ \\ Jonathan T.C. Kwan ${ }^{d}$ Ghodrat A. Siami ${ }^{\mathrm{C}}$ \\ on behalf of the SPD405-309 Lanthanum Study Group \\ a Manchester Royal Infirmary, Manchester, UK; ${ }^{b}$ Barnett Research and Communications, Torrance, Calif., USA; \\ 'Nephrological Centre Berlin-Moabit, Berlin, Germany; ${ }^{\mathrm{d}}$ St. Helier Hospital, Carshalton, UK; e Vanderbilt University, \\ Nashville, Tenn., USA
}

\section{Key Words}

Lanthanum carbonate $\cdot$ Hyperphosphatemia $\cdot$ Clinical trial

\begin{abstract}
Background/Aims: Lanthanum carbonate (LC, FOSRENOL $\left.{ }^{\circledR}\right)$ is an effective phosphate binder for which tolerability and a safety profile have been reported in haemodialysis patients. Patients from previous studies entered a 2-year extension, enabling assessment of efficacy and safety for up to 6 years of LC monotherapy. Methods: Patients from four previous trials entered this study. Results: Ninety-three patients started the extension, with 22 entering a sixth year of $L C$ treatment. Two-thirds of all patients received LC doses of 2,250 or 3,000 mg/day. Reductions in serum phosphate and calcium $\times$ phosphate product were maintained for up to 6 years. There were no new or unexpected adverse events (AEs), and no increase in the incidence of events with increasing treatment exposure. Over the complete duration of therapy, treatment-related AEs occurred in $25.8 \%$ of patients and were primarily gastrointestinal in nature. No clinically relevant changes in liver function tests were observed and there was no evidence of adverse effects on the liver, bone or the
\end{abstract}

central nervous system. Conclusions: LC monotherapy was effective and well tolerated for up to 6 years with no evidence of safety concerns or increased frequency of AEs.

Copyright $\odot 2008$ S. Karger AG, Basel

\section{Introduction}

Hyperphosphatemia is a common complication in patients with chronic kidney disease (CKD) stage 5 on hemodialysis. Although dialysis and dietary restrictions are capable of reducing serum phosphate to a limited extent, the majority of patients will require additional treatment with phosphate binders to reduce serum phosphate concentrations to the target range of 1.13-1.77 mmol/l (3.5$5.5 \mathrm{mg} / \mathrm{dl}$ ), as recommended in the $2003 \mathrm{Kidney}$ Disease Outcomes Quality Initiative (KDOQI) guidelines [1].

Lanthanum carbonate (FOSRENOL ${ }^{\circledR}$, Shire Pharmaceuticals) is a highly effective phosphate binder. Preclinical studies have shown that lanthanum binds phosphate equally well at all relevant $\mathrm{pH}$ levels throughout the gastrointestinal tract $[2,3]$. In short-term, placebo-controlled clinical trials, lanthanum carbonate was signifi-

\section{KARGER}

Fax +4161306 1234 E-Mail karger@karger.ch www.karger.com
(C) 2008 S. Karger AG, Basel

$1660-2110 / 08 / 1101-0015 \$ 24.50 / 0$

Accessible online at:

www.karger.com/nec
Dr. Alastair J. Hutchison

Consultant Nephrologist, Manchester Royal Infirmary

Oxford Road, Manchester, M13 9WL (UK)

Tel. +44 161276 1234, Fax +44 1612768022

E-Mail alastair.hutchison@cmmc.nhs.uk 
cantly more effective than placebo in reducing serum phosphate levels, with a safety profile similar to that of placebo and a rapid onset of action within 1-2 weeks [46]. In a 6-month, treat-to-target, comparative study of lanthanum carbonate versus calcium carbonate, the efficacy and safety profile of the two agents were similar [7]. Lanthanum carbonate, however, was associated with a substantially lower incidence of hypercalcemia [7]. The efficacy and tolerability of lanthanum carbonate monotherapy in comparison with alternative phosphate-binder therapy (which included calcium salts, sevelamer hydrochloride or aluminum, taken as monotherapy or combination therapy) has now been demonstrated in studies of up to 2 years' duration [8]. In addition, data from an open-label study have shown that the efficacy and safety profiles of lanthanum carbonate are maintained for up to 3 years of treatment; two-thirds of patients required a dose of either 2,250 or 3,000 mg/day [9], which is equivalent to three tablets per day (one during each meal).

Here, we present further data on the efficacy, tolerability and safety of lanthanum carbonate obtained during follow-up of patients who received long-term monotherapy for up to 6 years. This is the longest treatment followup of phosphate-binder therapy published to date.

\section{Patients and Methods}

\section{Design}

Patients from four previous studies received lanthanum carbonate in a final 2-year open-label extension (fig. 1). Study 1 was a European, randomized, open-label, 6-month, comparative study in which patients received lanthanum carbonate $(\mathrm{n}=533$, up to $3,000 \mathrm{mg} /$ day) or calcium carbonate $(\mathrm{n}=267$, up to 9,000 $\mathrm{mg} /$ day) [7]. This was followed by a 6 -month noncomparative phase $(\mathrm{n}=518)$ during which lanthanum carbonate-treated patients continued to take their established maintenance dose, and calcium carbonate-treated patients switched to lanthanum carbonate (375-3,000 mg/day). Patients could then enter a further 2 -year extension $(n=161)$, the results from which (after 3 years of lanthanum carbonate treatment) have been published [9]. This study was subsequently extended for a total treatment duration of up to 4 years. Study 2 was a European, randomized, open-label, 1 -year, comparative study of lanthanum carbonate ( $\mathrm{n}=49$, up to $3,750 \mathrm{mg} /$ day) versus calcium carbonate $(\mathrm{n}=49$, up to $9,000 \mathrm{mg} /$ day) [10]. Study 3 was a US, 2-year, randomized, open-label comparative study of lanthanum carbonate $(\mathrm{n}=682$, up to $3,000 \mathrm{mg} /$ day) versus alternative phosphate-binder therapy $(n=677)[8]$ and study 4 was a 1-year, open-label extension to two previous US randomized, double-blind, placebo-controlled studies ( $\mathrm{n}=77$, up to $3,000 \mathrm{mg} /$ day) [11].

Patients who were enrolled in this final extension continued open-label treatment with lanthanum carbonate for up to an additional 2 years. The extension could be entered by patients im- mediately on completion of their previous study or after a gap in treatment. Those patients who had a gap started treatment on the last dose of lanthanum carbonate that they received in their previous study, followed by titration visits as necessary. Patients from study 1 who participated in all the extension phases could have received up to 6 years' lanthanum carbonate treatment.

Although serum phosphate targets were stipulated in the protocols of three of the original studies ( $\leq 1.80 \mathrm{mmol} / 1$ [5.58 $\mathrm{mg} / \mathrm{dl}]$ in study 1 and $\leq 1.90 \mathrm{mmol} / 1$ [5.89 $\mathrm{mg} / \mathrm{dl}]$ in studies 3 and 4$)$, no target serum phosphate level was specified for this final extension study.

\section{Patients}

Male and female patients aged 18 years or older who participated in any of the four previous studies and who continued to require treatment for hyperphosphatemia were eligible for this open-label extension. Patients who withdrew from any of the previous studies before randomization, or who withdrew because of an adverse event (AE) considered by the investigators to have a possible relationship with lanthanum carbonate, were not eligible. Pregnant and lactating women were excluded, as were women with childbearing potential who did not consent to use an effective method of contraception. The study was approved by the Independent Ethics Committee and Institutional Review Boards, and conducted according to International Conference on Harmonization (ICH) Guidelines for Good Clinical Practice. Written informed consent was obtained from all patients.

\section{Endpoints}

Patients were followed up every 3 months during the 2-year extension. Efficacy and safety data are reported in conjunction with that from the previous studies giving a total treatment duration of up to 6 years. Treatment exposure years were defined as: year $1=>0$ to $<1$ year of treatment; year $2=1$ to $<2$ years; year $3=2$ to $<3$ years; year $4=3$ to $<4$ years; year $5=4$ to $<5$ years; year $6=\geq 5$ years. Efficacy endpoints included pre-dialysis serum phosphate and calcium $\times$ phosphate product levels. The tolerability and safety of lanthanum carbonate was assessed by recording AEs and by monitoring laboratory values.

\section{Results}

\section{Patient Disposition and Dosing}

In total, 93 patients entered the 2-year, open-label extension: 52 from the USA and 41 from Europe (table 1). These patients had been previously enrolled in studies of lanthanum carbonate, therefore they entered this final extension with variable total exposure times up to a maximum of 4 years. As the four initial studies ended at different times, there was a variable gap in treatment prior to the start of the final extension study. Of the 93 patients enrolled in the study, 65 had a treatment gap of less than 6 months between the last lanthanum carbonate dose in their initial trial and entry into the 2 -year extension. 
Fig. 1. Overview of study timelines feeding into the 2-year extension.

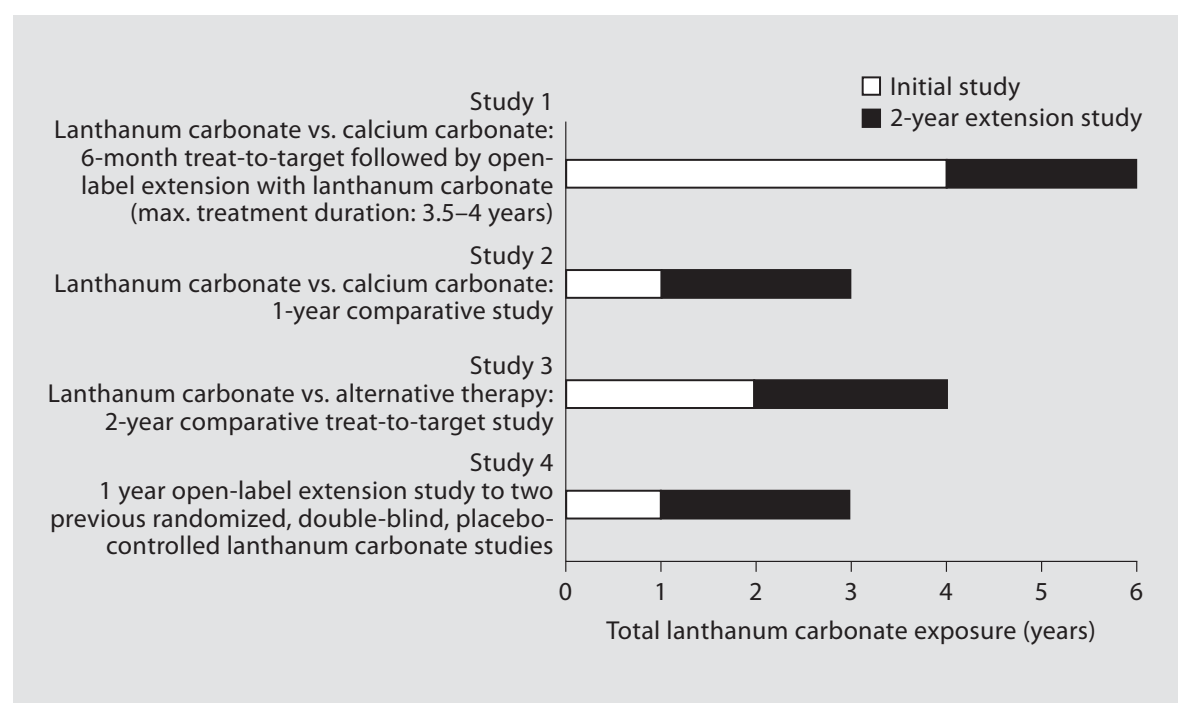

At the end of the additional 2-year extension, 86 patients had received at least 2 years' treatment with lanthanum carbonate. A total of 56 had a treatment duration of at least 3 years, 36 had a duration of at least 4 years and 22 of at least 5 years. Over the complete duration of treatment, the average daily dose of lanthanum carbonate was at the two highest doses of 2,250 or $3,000 \mathrm{mg}$ in $65.6 \%$ of patients (table 2). At some point during up to 6 years of lanthanum carbonate treatment, 77 patients received vitamin D compounds; 46 patients had their dose adjusted.

The most common reason for patients not completing the full extension phase was kidney transplant (table 3). There were five deaths during the study and 10 immediately following discontinuation due to AEs. None of these deaths were considered to be related to the study drug and were consistent with the expected mortality in this patient population [12].

\section{Efficacy}

During lanthanum carbonate treatment, even though no target was specified, reduction of serum phosphate (fig. 2) and calcium $\times$ phosphate product (fig. 3) levels was successfully maintained for up to 6 years. Serum phosphate (mean $\pm \mathrm{SD}$ ) levels were $2.52 \pm 0.68 \mathrm{mmol} /$ $1(7.80 \pm 2.10 \mathrm{mg} / \mathrm{dl})$ at baseline, reducing to $1.77 \pm 0.55$ $\mathrm{mmol} / \mathrm{l}(5.50 \pm 1.70 \mathrm{mg} / \mathrm{dl})$ after 6 months, $1.85 \pm 0.49$ $\mathrm{mmol} / \mathrm{l}(5.74 \pm 1.53 \mathrm{mg} / \mathrm{dl})$ after 3 years (month 36$)$, and $1.69 \pm 0.38 \mathrm{mmol} / \mathrm{l}(5.23 \pm 1.19 \mathrm{mg} / \mathrm{dl})$ after 5 years (month 60). The range of values at 6 years (month $72,1.45-2.10 \mathrm{mmol} / \mathrm{l}[4.5-6.5 \mathrm{mg} / \mathrm{dl}]$ ) was within the

Table 1. Demographics of patients entering the 2-year extension

\begin{tabular}{lccc}
\hline & $\begin{array}{l}\text { US } \\
\text { patients } \\
(\mathrm{n}=52)\end{array}$ & $\begin{array}{l}\text { European } \\
\text { patients } \\
(\mathrm{n}=41)\end{array}$ & Total \\
& $(\mathrm{n}=93)$ \\
\hline Age, mean $\pm \mathrm{SD}$, years & $54.5 \pm 15.2$ & $51.7 \pm 13.0$ & $53.2 \pm 14.3$ \\
Sex & $36(69.2 \%)$ & $28(68.3 \%)$ & $64(68.8 \%)$ \\
$\quad$ Male & $16(30.7 \%)$ & $13(31.7 \%)$ & $29(31.2 \%)$ \\
$\quad$ Female & $24(46.2 \%)$ & 0 & $24(25.8 \%)$ \\
$\begin{array}{l}\text { Ethnic origin } \\
\text { Black }\end{array}$ & $21(40.4 \%)$ & $40(97.6 \%)$ & $61(65.6 \%)$ \\
$\quad$ Caucasian & $7(13.5 \%)$ & 0 & $7(7.5 \%)$ \\
$\quad$ Hispanic & 0 & $1(2.4 \%)$ & $1(1.1 \%)$ \\
$\quad$ Other & & &
\end{tabular}

Table 2. Lanthanum exposure by total daily dose

\begin{tabular}{llllll}
\hline \multirow{2}{*}{$\begin{array}{l}\text { Treatment } \\
\text { year }\end{array}$} & \multicolumn{4}{l}{ Patients } \\
\cline { 2 - 6 } & $750 \mathrm{mg}$ & $1,500 \mathrm{mg}$ & $2,250 \mathrm{mg}$ & $3,000 \mathrm{mg}$ & total \\
\hline Year 1 & $5(5.4)$ & $27(29.0)$ & $36(38.7)$ & $25(26.9)$ & $93(100.0)$ \\
Year 2 & $5(5.4)$ & $26(28.0)$ & $36(38.7)$ & $25(26.9)$ & $92(98.9)$ \\
Year 3 & $5(5.4)$ & $25(26.9)$ & $34(36.6)$ & $22(23.7)$ & $86(92.5)$ \\
Year 4 & $1(1.1)$ & $18(19.4)$ & $22(23.7)$ & $15(16.1)$ & $56(60.2)$ \\
Year 5 & $1(1.1)$ & $13(14.0)$ & $12(12.9)$ & $10(10.8)$ & $36(38.7)$ \\
Year 6 & $1(1.1)$ & $9(9.7)$ & $6(6.5)$ & $6(6.5)$ & $22(23.7)$ \\
\hline
\end{tabular}

Treatment exposure years were defined as: year $1=>0$ to $<1$ year of treatment; year $2=1$ to $<2$ years; year $3=2$ to $<3$ years; year $4=3$ to $<4$ years; year $5=4$ to $<5$ years; year $6=\geq 5$ years.

Figures in parentheses are percentages 


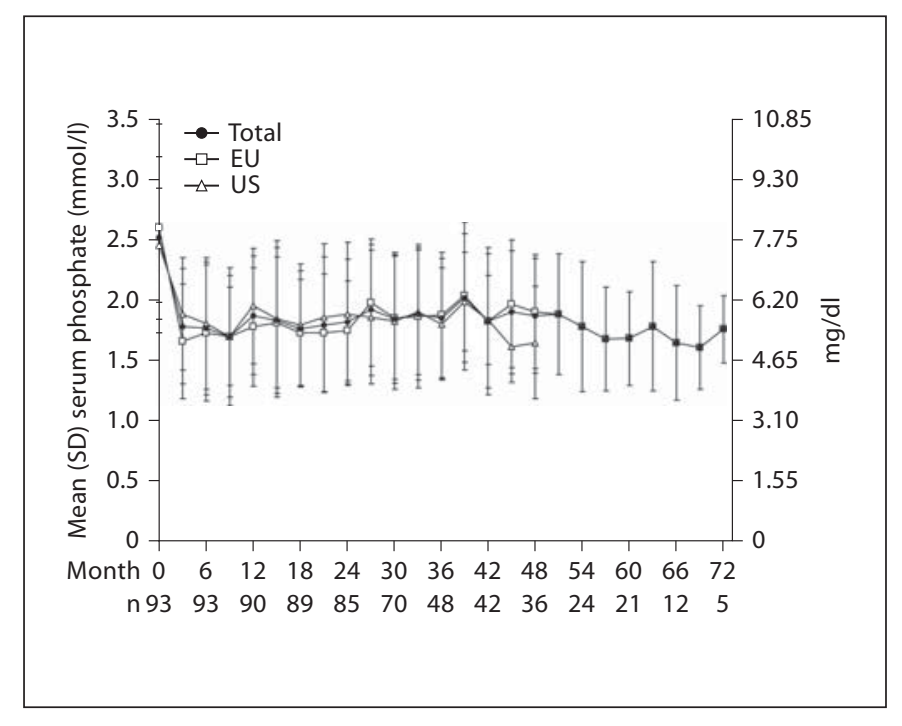

Fig. 2. Mean $( \pm S D)$ serum phosphate levels throughout treatment with lanthanum carbonate ( $\mathrm{n}=$ number of patients in the study at specified month).

Table 3. Reasons for withdrawal (total patients, $\mathrm{n}=93$ )

\begin{tabular}{lc}
\hline Number of patients who discontinued & $61(65.6 \%)$ \\
Received kidney transplant & $16(17.2 \%)$ \\
Other reasons* & $14(15.1 \%)$ \\
Death & $5(8.2 \%)$ \\
Withdrew consent & $13(14.0 \%)$ \\
Adverse event & $12(19.7 \%)$ \\
Protocol violation & $1(1.1 \%)$
\end{tabular}

* 'Other reasons' included: study ended after 1 year as per the original protocol $(n=4)$, problems with dialysis centre access $(n=3)$, non-compliance $(n=3)$, pregnancy $(n=1)$, pre-existing medical condition $(n=1)$, entered study prior to informed consent approval $(n=1)$ and lack of efficacy $(n=1)$.

range seen at earlier time points (e.g. month 36, 1.10$3.27 \mathrm{mmol} / \mathrm{l}[3.28-10.13 \mathrm{mg} / \mathrm{dl}])$. Because treatment practices and goals are known to differ between the USA and Europe, these cohorts were also analyzed separately. Mean serum phosphate levels at baseline were $2.45 \pm 0.48 \mathrm{mmol} / \mathrm{l}(7.61 \pm 1.48 \mathrm{mg} / \mathrm{dl})$ in US patients and $2.60 \pm 0.87 \mathrm{mmol} / \mathrm{l}(8.05 \pm 2.69 \mathrm{mg} / \mathrm{dl})$ in European patients. At 4 years (month 48), levels were $1.65 \pm$ $0.46 \mathrm{mmol} / \mathrm{l}(5.12 \pm 1.44 \mathrm{mg} / \mathrm{dl})$ in US patients and 1.91 $\pm 0.47 \mathrm{mmol} / \mathrm{l}(5.91 \pm 1.45 \mathrm{mg} / \mathrm{dl})$ in European patients.

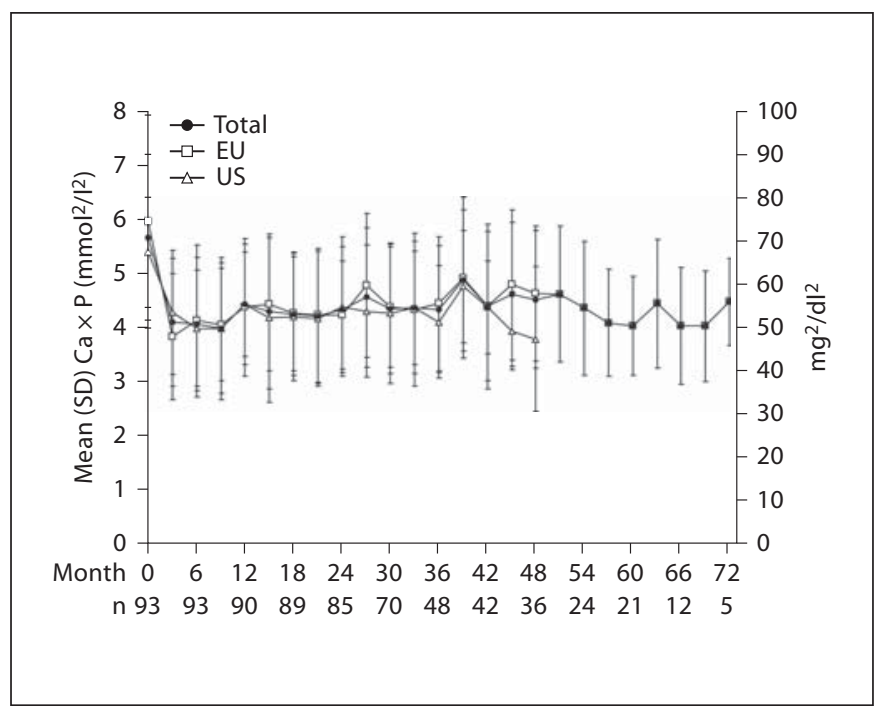

Fig. 3. Mean $( \pm S D)$ serum calcium $\times$ phosphate product levels throughout treatment with lanthanum carbonate ( $\mathrm{n}=$ number of patients in the study at specified month).

Overall calcium $\times$ phosphate product levels were 5.66 $\pm 1.53 \mathrm{mmol}^{2} / \mathrm{l}^{2}\left(70.2 \pm 19.0 \mathrm{mg}^{2} / \mathrm{dl}^{2}\right)$ at baseline, reducing to $4.07 \pm 1.23 \mathrm{mmol}^{2} / \mathrm{l}^{2}\left(50.4 \pm 15.2 \mathrm{mg}^{2} / \mathrm{dl}^{2}\right)$ after 6 months, $4.33 \pm 1.17 \mathrm{mmol}^{2} / \mathrm{l}^{2}\left(53.75 \pm 14.51 \mathrm{mg}^{2} / \mathrm{dl}^{2}\right)$ after 3 years (month 36$)$ and $4.04 \pm 0.91 \mathrm{mmol}^{2} / \mathrm{dl}^{2}(50.05$ $\pm 11.30 \mathrm{mg}^{2} / \mathrm{dl}^{2}$ ) after 5 years (month 60 ). The range of values at 6 years (month 72, 3.83-5.64 $\mathrm{mmol}^{2} / \mathrm{l}^{2}[46.4-$ $\left.68.2 \mathrm{mg}^{2} / \mathrm{dl}^{2}\right]$ ) was within the range seen at earlier timepoints (e.g. month $36,2.40-7.48 \mathrm{mmol}^{2} / \mathrm{dl}^{2}$ [29.5-92.7 $\left.\mathrm{mg}^{2} / \mathrm{dl}^{2}\right]$ ). In US and European patients, baseline calcium $\times$ phosphate product levels were $5.43 \pm 1.03 \mathrm{mmol}^{2} / \mathrm{l}^{2}$ $(67.4 \pm 12.7)$ and $5.96 \pm 1.98 \mathrm{mmol}^{2} / \mathrm{l}^{2}\left(73.9 \pm 24.5 \mathrm{mg}^{2} /\right.$ $\mathrm{dl}^{2}$ ), respectively. At 4 years (month 48 ), calcium $\times$ phosphate product levels were $3.82 \pm 1.35 \mathrm{mmol}^{2} / 1^{2}(47.4 \pm$ $\left.16.8 \mathrm{mg}^{2} / \mathrm{dl}^{2}\right)$ in US patients and $4.63 \pm 1.24 \mathrm{mmol}^{2} / \mathrm{l}^{2}$ $\left(57.4 \pm 15.4 \mathrm{mg}^{2} / \mathrm{dl}^{2}\right)$ in European patients.

\section{Safety Profile and Tolerability}

There were no new or unexpected AEs, or any increase in the incidence of AEs with increasing exposure to lanthanum carbonate over long-term treatment (up to 6 years). The most common AEs occurring at any point during the treatment period were episodes of myalgia in 48 patients (51.6\%), nausea in 46 patients (49.5\%), hypotension in 39 patients (41.9\%) and 'influenza-like symptoms' in 38 patients (40.9\%). There was a low incidence of hypercalcemia in 5 patients $(5.4 \%)$ and hypocalcemia (mostly transient) in 10 patients $(10.8 \%)$. 


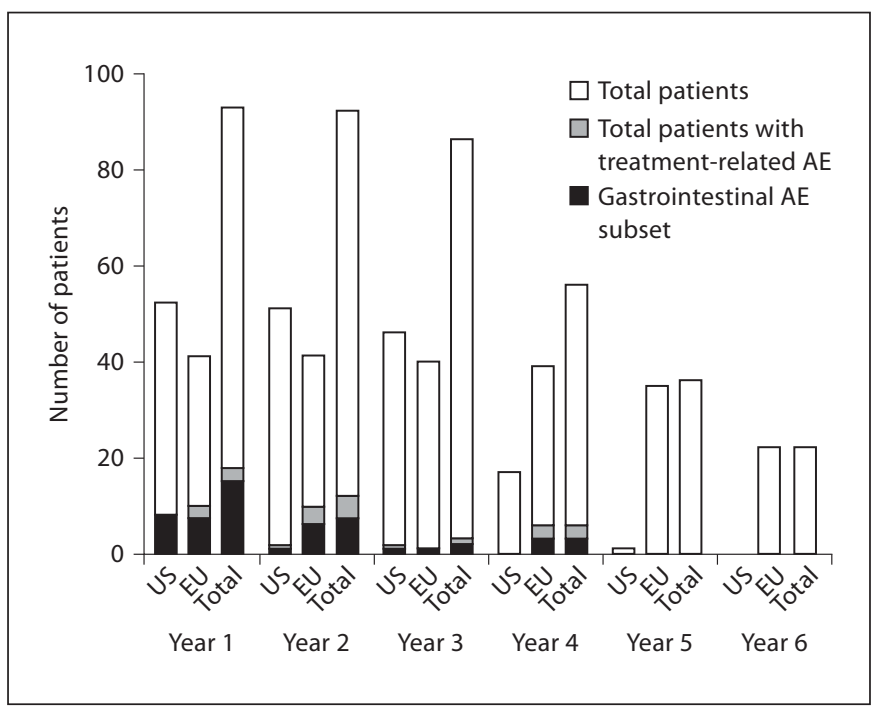

Fig. 4. Patients with treatment-related adverse events by year of lanthanum carbonate exposure.

During the total treatment period, AEs that were considered by the investigators to be related to lanthanum carbonate treatment occurred in 24 patients (25.8\%), with the most common being gastrointestinal in nature (mainly nausea, diarrhea and flatulence). Because there are known cultural, demographic and regional medical differences between the USA and Europe, AEs were also assessed separately in these cohorts. Treatment-related AEs of the gastrointestinal tract occurred in 8 patients in the US cohort (15.4\%) and in 11 patients (26.8\%) in the European cohort. No gastrointestinal events were reported in US patients after 3 years of lanthanum carbonate exposure, or in European patients after 4 years of exposure (fig. 4). Overall, there was no evidence of any increase in the incidence of treatment-related AEs with increasing exposure.

There was one serious treatment-related AE, but it did not cause the patient to withdraw from the study. This was a case of worsening gastritis in a 51-year-old man from Germany who had a previous history of gastritis, abdominal-wall abscess and peritonitis. He had received lanthanum carbonate for almost 5 years and at the time of the event was receiving a dose of 3,000 $\mathrm{mg}$ /day.

There were $12 \mathrm{AEs}$ that led to discontinuation and 10 of them resulted in death. AEs leading to death included myocardial infarction, heart failure, sepsis, cerebral hemorrhage, anoxic brain damage and voluntary discontinuation of dialysis. The other two events leading to with- drawal were dyspepsia and elevated liver function tests (believed to be secondary to liver hemangiomas). None of the AEs leading to withdrawal were considered to be related to treatment.

The median plasma lanthanum level at baseline (i.e. before lanthanum carbonate treatment in initial studies) was $0.0 \mathrm{ng} / \mathrm{ml}$ (range: $0.0-0.2 \mathrm{ng} / \mathrm{ml}$ ). This rose to $0.3 \mathrm{ng} /$ $\mathrm{ml}$ (range: $0.0-4.2 \mathrm{ng} / \mathrm{ml}$ ) after 6 months of lanthanum carbonate treatment and was in the range of $0-13.9 \mathrm{ng} / \mathrm{ml}$ over the total treatment duration. The relatively high number of $13.9 \mathrm{ng} / \mathrm{ml}$ was due to an outlying value in a patient who had this level recorded at a single study visit (after 18 months of lanthanum carbonate treatment). Apart from an additional value of $4.0 \mathrm{ng} / \mathrm{ml}$ recorded after 12 months of treatment, all other samples collected from this patient (over 48 months of treatment) showed plasma lanthanum levels of $0.6-1.0 \mathrm{ng} / \mathrm{ml}$. Over the total treatment duration (574 measurements from 93 patients), plasma lanthanum levels greater than $2.0 \mathrm{ng} / \mathrm{ml}$ were recorded on only 15 occasions, and levels greater than 4.0 $\mathrm{ng} / \mathrm{ml}$ on only 4 occasions (highest value other than the outlier was $4.3 \mathrm{ng} / \mathrm{ml}$ ).

No clinically relevant changes in liver enzymes (aspartate aminotransferase and alanine aminotransferase) and bilirubin levels were observed at any time during treatment with lanthanum carbonate (table 4). There was a low incidence of liver and biliary system AEs reported during the observation period (table 5) and no event was considered likely to be related to treatment.

No adverse effects on levels of hematological laboratory parameters, including serum hemoglobin, hematocrit and mean cell volume, were noted after up to 6 years of treatment.

Serum levels of calcium, parathyroid hormone (PTH), bone-specific alkaline phosphatase and osteocalcin generally remained stable over the treatment period (table 6). There was a low incidence of fractures and bone-related musculoskeletal AEs. Over the total treatment duration, fractures were reported in only 4 patients (4.3\%).

Only two central and peripheral nervous system AEs were considered likely to be related to treatment. These were episodes of headache (one in each of 2 patients) that occurred in the first year of lanthanum carbonate exposure. Both events resolved with continuing treatment with lanthanum carbonate. Overall, AEs relating to the central and peripheral nervous systems occurred in 67 patients (72.0\%) during the total treatment duration. The most common of these were headache and dizziness, and no increase in incidence occurred with increasing exposure to treatment. 
Table 4. Levels of liver enzymes (aspartate aminotransferase [AST], alanine aminotransferase [ALT]) and bilirubin in patients receiving lanthanum carbonate for up to 6 years

\begin{tabular}{llllllll}
\hline Month & Baseline & 12 & 24 & 36 & 48 & 60 & 72 \\
\hline $\begin{array}{l}\text { AST, U/l } \\
\quad \text { n }\end{array}$ & 46 & 50 & 46 & 18 & 33 & 22 & 5 \\
$\quad$ Mean & 17.2 & 20.5 & 18.7 & 17.2 & 16.8 & 17.9 & 15.8 \\
$\quad$ Median & 17.0 & 18.0 & 18.0 & 15.0 & 17.0 & 17.5 & 18.0 \\
$\quad$ Range & $3-46$ & $6-131$ & $6-53$ & $0-34$ & $5-33$ & $7-43$ & $12-18$ \\
ALT, U/l & & & & & & & 5 \\
$\quad$ n & 87 & 89 & 85 & 49 & 35 & 22 & 16.6 \\
$\quad$ Mean & 17.3 & 17.9 & 18.3 & 18.5 & 17.3 & 20.4 & 16.0 \\
$\quad$ Median & 14.0 & 15.0 & 17.0 & 17.0 & 17.0 & 16.0 & $11-25$ \\
$\quad$ Range & $4-96$ & $3-57$ & $6-61$ & $5-58$ & $2-64$ & $8-40$ & 5 \\
Bilirubin, $\mu$ mol/1 & & & & & & & \\
$\quad$ n & 88 & 89 & 84 & 49 & 35 & 22 & 4.45 \\
$\quad$ Mean & 6.48 & 6.74 & 6.82 & 7.76 & 6.00 & 4.82 & 3.42 \\
$\quad$ Median & 6.02 & 6.84 & 6.72 & 7.51 & 5.13 & 3.42 & $3.4-8.6$ \\
$\quad$ Range & $3.4-13.2$ & $3.4-13.7$ & $3.4-13.9$ & $3.4-17.6$ & $3.4-17.1$ & $3.4-8.6$ \\
\hline
\end{tabular}

\section{Discussion}

The mortality and morbidity of patients with CKD stage 5 have improved as a result of advances in dialysis treatment and our understanding of the pathophysiology of uremia. However, the average survival for dialysis patients aged $50-54$ years is still less than 6 years, and this falls to less than 48 months in patients aged 65 years and over, unless they undergo renal transplantation [12]. The long-term efficacy, tolerability and safety profile of phosphate binders is clearly of great importance, but such studies are difficult as fitter patients tend to be transplanted and those that are less fit may die prematurely. Concern has been expressed about the possibility of lanthanum accumulation with long-term use [13]. Plasma lanthanum levels remained low over up to 6 years of lanthanum carbonate treatment, and were of similar magnitude $(\sim 1 \mathrm{ng} / \mathrm{ml})$ to the levels observed in previous trials of shorter duration [9]. While there has been debate about the value of monitoring plasma lanthanum levels [14, 15], there was no evidence of exposure-related adverse effects. The patients who completed our study are a self-selected group and therefore conclusions should be drawn with caution. However, there is no reason to suggest that this group would be protected from lanthanum accumulation if it were occurring and our data demonstrated that treatment for up to 6 years was not associated with any discernable adverse effects.
Overall, the results from this present long-term follow-up of dialysis patients receiving lanthanum carbonate indicate that the efficacy, tolerability and safety profile of treatment may be maintained for up to 6 years. The type and frequency of adverse events over up to 6 years of treatment was as expected given that dialysis patients typically suffer from multiple co-morbidities and receive several different medications. Importantly, there was no increase in the frequency of treatment-related AEs with increasing exposure, there were no new AEs (those not previously reported in 1- to 2-year comparative studies with lanthanum carbonate), and there were no unexpected or clinically significant findings on laboratory biochemical and hematological tests.

Two-thirds of patients in this study received the highest lanthanum carbonate doses of either 2,250 or 3,000 $\mathrm{mg} /$ day. At these doses, up to 6 years of lanthanum carbonate treatment in this long-term follow-up was not associated with any clinically relevant effects on the liver, bone, central nervous system or any other body system. These results are consistent with previous clinical and preclinical studies involving lanthanum [10, 13, 16-24].

This is the longest study published to date on the continued administration of phosphate-binder therapy. A 3year study of calcium carbonate, published in 1993, reported an initial control of serum phosphate levels but a constant, effective phosphate reduction could not be achieved when treated over the long term [25]. Although the primary purpose of the long-term follow-up reported 
Table 5. Patients with liver and biliary system adverse events over 6 years of lanthanum carbonate treatment: no event was considered likely to be related to lanthanum carbonate treatment

\begin{tabular}{|c|c|c|c|c|c|c|c|c|c|c|c|c|}
\hline \multirow{2}{*}{$\begin{array}{l}\text { Number of patients } \\
\text { (\%) at beginning } \\
\text { of year }\end{array}$} & \multicolumn{2}{|l|}{ Year 1} & \multicolumn{2}{|l|}{ Year 2} & \multicolumn{2}{|l|}{ Year 3} & \multicolumn{2}{|l|}{ Year 4} & \multicolumn{2}{|l|}{ Year 5} & \multicolumn{2}{|l|}{ Year 6} \\
\hline & $\begin{array}{l}\text { US } \\
(\mathrm{n}=52)\end{array}$ & $\begin{array}{l}\mathrm{EU} \\
(\mathrm{n}=41)\end{array}$ & $\begin{array}{l}\text { US } \\
(n=51)\end{array}$ & $\begin{array}{l}\mathrm{EU} \\
(\mathrm{n}=41)\end{array}$ & $\begin{array}{l}\text { US } \\
(\mathrm{n}=46)\end{array}$ & $\begin{array}{l}\mathrm{EU} \\
(\mathrm{n}=40)\end{array}$ & $\begin{array}{l}\text { US } \\
(n=17)\end{array}$ & $\begin{array}{l}\mathrm{EU} \\
(\mathrm{n}=39)\end{array}$ & $\begin{array}{l}\text { US } \\
(\mathrm{n}=1)\end{array}$ & $\begin{array}{l}\mathrm{EU} \\
(\mathrm{n}=35)\end{array}$ & $\begin{array}{l}\text { US } \\
(\mathrm{n}=0)\end{array}$ & $\begin{array}{l}\mathrm{EU} \\
(\mathrm{n}=22)\end{array}$ \\
\hline Cholelithiasis & $1(1.9)$ & & & & & & & $1(2.6)$ & & $2(5.7)$ & & \\
\hline Hepatic enzymes increa & eased & $1(2.4)$ & & & & & & & & $1(2.9)$ & & \\
\hline Hepatitis cholestatic & & $1(2.4)$ & & & & & & & & & & \\
\hline Hepatomegaly & $1(1.9)$ & & $1(2.0)$ & & & & & & & & & \\
\hline GGT increased & & & $1(2.0)$ & & $2(4.3)$ & & & & & & & \\
\hline
\end{tabular}

GGT = Gamma-glutamyltranspeptidase. Treatment exposure years were defined as: year $1=>0$ to $<1$ year of treatment; year $2=1$ to $<2$ years; year $3=2$ to $<3$ years; year $4=3$ to $<4$ years; year $5=4$ to $<5$ years; year $6=\geq 5$ years. Empty cells indicate no events observed.

Table 6. Serum levels of calcium, parathyroid hormone (PTH), bone-specific alkaline phosphatase and osteocalcin in patients receiving lanthanum carbonate for up to 6 years

\begin{tabular}{|c|c|c|c|c|c|c|c|}
\hline & Baseline & 12 months & 24 months & 36 months & 48 months & 60 months & 72 months \\
\hline \multicolumn{8}{|c|}{ Calcium, mmol/1 ${ }^{\mathrm{a}}$} \\
\hline $\mathrm{n}$ & 93 & 90 & 85 & 49 & 36 & 22 & 5 \\
\hline Mean & 2.27 & 2.38 & 2.39 & 2.35 & 2.40 & 2.39 & 2.54 \\
\hline Median & 2.30 & 2.40 & 2.40 & 2.35 & 2.39 & 2.43 & 2.48 \\
\hline Range & $0.90-3.15$ & $1.40-2.95$ & $1.80-2.88$ & $1.70-2.65$ & $1.76-2.80$ & $2.03-2.73$ & $2.28-2.78$ \\
\hline \multicolumn{8}{|l|}{ PTH, ng/l } \\
\hline $\mathrm{n}$ & 87 & 71 & 65 & 33 & 33 & 18 & 3 \\
\hline Mean & 224 & 261 & 205 & 244 & 212 & 246 & 408 \\
\hline Median & 147 & 219 & 155 & 190 & 165 & 201 & 425 \\
\hline Range & $7-1,404$ & $9-981$ & $17-621$ & $52-706$ & $0-791$ & $28-654$ & $161-639$ \\
\hline \multicolumn{8}{|c|}{ Bone-specific alkaline phosphatase, $\mathrm{ng} / \mathrm{ml}$} \\
\hline $\mathrm{n}$ & 44 & 46 & 45 & 18 & 33 & 18 & 4 \\
\hline Mean & 21.6 & 29.1 & 25.8 & 28.8 & 25.4 & 30.5 & 25.2 \\
\hline Median & 15.2 & 17.6 & 17.9 & 16.2 & 15.8 & 22.0 & 27.8 \\
\hline Range & $2.8-105.9$ & $4.0-306.8$ & $3.7-83.7$ & $5.4-80.0$ & $5.7-169.7$ & $6.8-102.4$ & $13.2-32.0$ \\
\hline \multicolumn{8}{|c|}{ Osteocalcin, $\mathrm{nmol} / \mathrm{l}^{\mathrm{b}}$} \\
\hline $\mathrm{n}$ & 43 & 47 & 45 & 17 & 35 & 20 & 5 \\
\hline Mean & 58.04 & 50.66 & 59.32 & 57.10 & 43.44 & 59.29 & 99.24 \\
\hline Median & 29.82 & 36.90 & 42.75 & 41.88 & 29.53 & 43.30 & 106.02 \\
\hline Range & $6.07-244.19$ & $5.63-213.58$ & $3.69-198.19$ & $14.59-211.19$ & $3.73-123.53$ & $10.19-129.46$ & $23.94-166.62$ \\
\hline
\end{tabular}

a To convert to $\mathrm{mg} / \mathrm{dl}$, multiply by $4.0{ }^{\text {b }}$ to convert to $\mathrm{ng} / \mathrm{ml}$, multiply by 5.85 .

here was to provide additional data on the tolerability and safety profile of lanthanum carbonate treatment, efficacy was also monitored throughout. The results show that control of serum phosphate and calcium $\times$ phosphate product levels can be maintained for up to 6 years of treatment. Serum PTH levels also generally remained stable over up to 6 years of treatment. These data suggest that lanthanum carbonate can be used in combination with vitamin D to maintain control of PTH levels over the long term. 
In the present study, serum calcium levels during treatment with lanthanum carbonate were stable over time and a low incidence of hypercalcemia (5.4\%) was observed. A lower incidence was reported in study 1 , in which hypercalcemia was reported as an AE in $0.4 \%$ of patients receiving lanthanum carbonate compared with $20.2 \%$ of those receiving calcium [7]. Our results for lanthanum carbonate are consistent with study 1 given the different treatment durations (6 years vs. 6 months).

Clinical trials with a 'treat to target' design have shown that lanthanum carbonate has similar efficacy to alternative phosphate-binder therapy (which has included sevelamer hydrochloride) $[7,8]$, whereas in vitro studies have shown that lanthanum carbonate has a higher binding affinity and specificity for phosphate when compared both with calcium-based binders and sevelamer hydrochloride $[2,3]$. Thus, lanthanum carbonate has the potential to reduce tablet burden in patients with hyperphosphatemia. Two-thirds of patients enrolled in this longterm follow-up received a maintenance lanthanum carbonate dose of either 2,250 or $3,000 \mathrm{mg} /$ day, which is equivalent to one 750 or $1,000 \mathrm{mg}$ tablet during each meal for a total of three tablets per day.

The study is not without limitations, the most important of which is the open-label design, which therefore contains inherent bias. The patient cohort was an enriched selection in that they chose to stay on this treatment. As with any long-term follow-up, interpretation of the results is also limited by the small number of patients remaining in their sixth year of treatment, which is expected given the current life expectancy of dialysis patients. Despite these limitations, however, these data show that lanthanum carbonate exposure of up to 6 years was not associated with adverse safety issues and demonstrate that effective, well-tolerated, long-term phosphate-binder treatment can be achieved with lanthanum carbonate.

\section{Conclusions}

Lanthanum carbonate reduced and maintained control of serum phosphate and calcium $\times$ phosphate product levels for up to 6 years of treatment. Lanthanum carbonate was well tolerated, with no new or unexpected AEs reported. No increase in the incidence of treatmentrelated AEs occurred with increasing exposure to lanthanum. There was no evidence of adverse safety concerns after long-term lanthanum carbonate treatment in any body system, including the hepatic system, bone and central nervous system.

\section{Acknowledgements}

We thank the following investigators for their contributions to the SPD405-309 clinical study: Belgium: Dr. B. Maes, UZ Gasthuisberg Afdeling Hemodialyse (Leuven). Germany: Dr. L. Musselmann, KfH-Dialysezentrum (Rosenheim); Dr. W. Bagnewski, Arzt für Innere Medizin (Dülmen); Dr. E. Meyer, Dialysepraxis Altona (Hamburg); Dr. W. Backs, Dialysezentrum Barmbek (Hamburg); Dr. J. Schupp, KfH-Dialysezentrum (Lauf); Dr. R. Krause, KfH-Dialysezentrum (Berlin); Dr. G. Prager, Elisabethenstrasse 13 (Bad König); Dr. R. Scholz, Dialysezentrum (Bad Homburg); Dr. G. Asmus, KfH-Dialysezentrum (Berlin); Dr. E. J. Kirchertz, Arzt für Innere Medizin (Bad Münder); Dr. R. Böhm, KfH Zentrum (Aachen). Puerto Rico: Dr. J. Cangiano, Clinica Las Americas (San Juan). UK: Dr. J. Bradley, Addenrookes Hospital (Cambridge); Dr. A. J. Hutchison, Manchester Royal Infirmary (Manchester); Dr. J. Kwan, St. Helier Hospital (Carshalton). USA: Dr. F. Apantaku, Illinois Center for Clinical Research (Chicago); Dr. M. E. Barnett, Barnett Research and Communications Medical Corporation (Torrance); Dr. K. Boren, Southwest Kidney Institute, PLC (Tempe); Dr. L. Kirchner, Affiliated Hospitals at Carlton (Canton); Dr. E. Frederickson, SMO-USA (Conyers); Dr. M. Germain, Western New England Renal and Transplant Associates (Springfield); Dr. M. Kaplan, Nephrology Associates (Nashville); Dr. G. Keightley, MedSource, Inc. (Richmond); Dr. N. Kopyt, Northeast Clinical Research Centers, Inc. (Allentown); Dr. H. Locay, Discovery Medical Research Group (Ocala); Dr. P. Marin, Altru Health System Research Department (Grand Forks); Dr. H. Mawad, University of Kentucky Medical Center (Lexington); Dr. J. Middleton, University of Texas Southwestern (Dallas); Dr. R. Mosset, North Shore University (Great Neck); Dr. F. Osorio, Southwest Kidney Institute, PLC (Tempe); Dr. A. Qami, Odyssey Research Services (Fargo); Dr. G. Siami, VA Tennessee Valley Health Care System (Nashville); Dr. L. Steed, Northwest Renal Clinic (Portland); Dr. E. Tokatlian, Associated Internist Ahawatukee, PC (Phoenix); Dr. M. Weinberg, Hypertension and Nephrology Inc. Research Division (Providence); Dr. W. Weise, University of Vermont (Burlington).

Biocommunications Development Ltd. and Oxford PharmaGenesis $^{\mathrm{TM}}$ provided editorial support to the authors.

The study was funded by Shire Pharmaceuticals.

\section{Conflict of Interest}

The authors who participated in this study received funding as clinical investigators in trials of lanthanum carbonate funded by Shire Pharmaceuticals. In addition, A.H. has acted as a consultant to Shire Pharmaceuticals and been an invited speaker at Shire-sponsored clinical meetings. 


\section{References}

1 National Kidney Foundation: K/DOQI clinical practice guidelines for bone metabolism and disease in chronic kidney disease. Am J Kidney Dis 2003;42:S1-S201.

-2 Hutchison AJ: Improving phosphate-binder therapy as a way forward. Nephrol Dial Transplant 2004;19(suppl 1):i19-i24.

-3 Autissier V, Damment SJ, Henderson RA: Relative in vitro efficacy of the phosphate binders lanthanum carbonate and sevelamer hydrochloride. J Pharm Sci 2007;96:28182827.

4 Al-Baaj F, Speake M, Hutchison AJ: Control of serum phosphate by oral lanthanum carbonate in patients undergoing haemodialysis and continuous ambulatory peritoneal dialysis in a short-term, placebo-controlled study. Nephrol Dial Transplant 2005;20: 775-782.

$\checkmark 5$ Chiang SS, Chen JB, Yang WC: Lanthanum carbonate (Fosrenol) efficacy and tolerability in the treatment of hyperphosphatemic patients with end-stage renal disease. Clin Nephrol 2005;63:461-470.

6 Joy MS, Finn WF: Randomized, doubleblind, placebo-controlled, dose-titration, phase III study assessing the efficacy and tolerability of lanthanum carbonate: a new phosphate binder for the treatment of hyperphosphatemia. Am J Kidney Dis 2003;42: 96-107.

7 Hutchison AJ, Maes B, Vanwalleghem J, Asmus G, Mohamed E, Schmieder R, Backs W, Jamar R, Vosskuhler A: Efficacy, tolerability, and safety of lanthanum carbonate in hyperphosphatemia: a 6-month, randomized, comparative trial versus calcium carbonate. Nephron Clin Pract 2005;100:c8-c19.

-8 Finn WF: Lanthanum carbonate versus standard therapy for the treatment of hyperphosphatemia: safety and efficacy in chronic maintenance hemodialysis patients. Clin Nephrol 2006;65:191-202.
-9 Hutchison AJ, Maes B, Vanwalleghem J, Asmus G, Mohamed E, Schmieder R, Backs W, Jamar R, Vosskuhler A: Long-term efficacy and tolerability of lanthanum carbonate: results from a 3-year study. Nephron Clin Pract 2006;102:c61-c71.

10 D'Haese PC, Spasovski GB, Sikole A, Hutchison A, Freemont TJ, Sulkova S, Swanepoel C, Pejanovic S, Djukanovic L, Balducci A, Coen G, Sulowicz W, Ferreira A, Torres A, Curic S, Popovic M, Dimkovic N, De Broe ME: A multicenter study on the effects of lanthanum carbonate (Fosrenol) and calcium carbonate on renal bone disease in dialysis patients. Kidney Int Suppl 2003;64:S73-S78.

11 Finn WF, Joy MS: A long-term, open-label extension study on the safety of treatment with lanthanum carbonate, a new phosphate binder, in patients receiving hemodialysis. Curr Med Res Opin 2005;21:657-664.

12 United States Renal Data System: Annual Data Report. Bethesda, National Institute of Health, National Institute of Diabetes and Digestive and Kidney Diseases, 2005.

13 Slatopolsky E, Liapis H, Finch J: Progressive accumulation of lanthanum in the liver of normal and uremic rats. Kidney Int 2005;68: 2809-2813.

14 Lacour B, Lucas A, Auchere D, Ruellan N, de Serre Patey NM, Drueke TB: Chronic renal failure is associated with increased tissue deposition of lanthanum after 28-day oral administration. Kidney Int 2005;67:10621069

15 D’Haese PC, Behets GJ, De Broe ME, Damment SJ: Lanthanum pharmacokinetics: are rat data misleading? Kidney Int 2005;68: 2907-2908; author reply 8-9.

16 Damment SJ, Pennick M: Systemic lanthanum is excreted in the bile of rats. Toxicol Lett 2007;171:69-77.
17 Behets GJ, Verberckmoes SC, Oste L, Bervoets AR, Salome M, Cox AG, Denton J, De Broe ME, D'Haese PC: Localization of lanthanum in bone of chronic renal failure rats after oral dosing with lanthanum carbonate. Kidney Int 2005;67:1830-1836.

18 Behets GJ, Dams G, Vercauteren SR, Damment SJ, Bouillon R, De Broe ME, D’Haese PC: Does the phosphate binder lanthanum carbonate affect bone in rats with chronic renal failure? J Am Soc Nephrol 2004; 15:22192228

19 Behets GJ, Gritters M, Dams G, De Broe ME, D'Haese PC: Effects of efficient phosphate binding on bone in chronic renal failure rats. Ren Fail 2005;27:475-484.

20 Freemont AJ, Hoyland JA, Denton J: The effects of lanthanum carbonate and calcium carbonate on bone abnormalities in patients with end-stage renal disease. Clin Nephrol 2005;64:428-437.

21 Altmann P, Barnett ME, Finn WF: Cognitive function in Stage 5 chronic kidney disease patients on hemodialysis: no adverse effects of lanthanum carbonate compared with standard phosphate-binder therapy. Kidney Int 2007;71:252-259.

22 Shire Pharmaceutical Contracts Ltd: Fosrenol - Summary of Product Characteristics (UK), 2007.

23 Brancaccio D, Cozzolino M: Lanthanum carbonate: time to abandon prejudices? Kidney Int 2007;71:190-192.

24 Yang Z, Schryvers D, Roels F, D'Haese PC, De Broe ME: Demonstration of lanthanum in liver cells by energy-dispersive $\mathrm{X}$-ray spectroscopy, electron energy loss spectroscopy and high-resolution transmission electron microscopy. J Microsc 2006;223:133-139.

-25 Sperschneider H, Gunther K, Marzoll I, Kirchner E, Stein G: Calcium carbonate (CaCO3): an efficient and safe phosphate binder in haemodialysis patients? A 3-year study. Nephrol Dial Transplant 1993;8:530534

\section{Erratum}

In the above article by A.J. Hutchison et al. titled 'Long-term efficacy and safety profile of lanthanum carbonate: results for up to 6 years of treatment' [Nephron Clin Pract 2008;110:c15-c23], two of the percent values in table 3 should be changed. Under the heading death it should read $5.4 \%$ and for adverse event it should be $12.9 \%$. 